\title{
Electrokinetic Treatment for Model Caissons with Increasing Dimensions
}

\author{
Eltayeb Mohamedelhassan, Kevin Curtain, Matt Fenos, \\ Kevin Girard, Anthony Provenzano, and Wesley Tabaczuk \\ Department of Civil Engineering, Lakehead University, 955 Oliver Road, Thunder Bay, ON, Canada P7B 5W2 \\ Correspondence should be addressed to Eltayeb Mohamedelhassan, eltayeb@lakeheadu.ca
}

Received 24 September 2012; Accepted 16 November 2012

Academic Editor: Jean-Herve Prevost

Copyright (c) 2012 Eltayeb Mohamedelhassan et al. This is an open access article distributed under the Creative Commons Attribution License, which permits unrestricted use, distribution, and reproduction in any medium, provided the original work is properly cited.

\begin{abstract}
Electrokinetic treatment has been known in geotechnical engineering for over six decades, yet, the technique is rarely used. This stems from the absence of design guidelines and specifications for electrokinetic treatment systems. An important issue that need to be investigated and understood in order to devise guidelines from experimental results is the effect of the foundation element size on the outcome of the treatment. Also important is determining the optimum distance between the electrodes and estimating the energy consumption prior to treatment. This experimental study is a preliminary step in understanding some of the issues critical for the guidelines and specifications. Four model caissons with surface areas between 16000 and $128000 \mathrm{~mm}^{2}$ were embedded in soft clayey soil under water and treated for $168 \mathrm{hr}$ with a dc voltage of $6 \mathrm{~V}$. From the results, a distance between the anode (model caisson) and the cathode equal 0.25 times the outside diameter of the model caisson was identified as optimum. Relationships between the surface area and axial capacity of the model caisson and the surface area and energy consumption were presented. The equations can be used to preliminary estimate the load capacity and the energy consumption for full-scale applications.
\end{abstract}

\section{Introduction}

Soft soils and marine deposits are very common around the world. There are many infrastructure projects and coastal high-rise buildings whose foundations are often supported by such soils of low shear strength and high compressibility. Furthermore, exploration and development of oil and gas fields around the world and expansion of wind farms has resulted in the construction of many platforms and towers on offshore soils with low shear strength. The construction of these projects on soft soils can lead to very expensive foundation systems. Moreover, the installation of traditional foundation elements, particularly driven piles or caissons, can destroy any naturally existing cohesion or cementation between the soil particles and disturb the structure of the soil in the close vicinity of the foundation, causing excessive settlement and further reduction in the foundation's loading capacity.
Electrokinetic treatment is an effective soil improvement technique to increase shear strength and load capacity of foundation elements in soft soils. Electrokinetics improves the strength properties of soft soils by inducing electrokinetic consolidation (e.g., [1]), generating electrokinetic cementation (e.g., [2]) and reducing the water content (e.g., [3]). Major benefits of using electrokinetic treatment are the limited disturbance the treatment may cause to the existing soil structure and the ability to control the zone of treatment. Electrokinetic treatment has been known in geotechnical engineering for over six decades $[4,5]$ with successful laboratory scale investigations (e.g., $[6,7]$ ) and field experimentations (e.g., [8-10]). Furthermore, case records are reported where electrokinetics was successfully used to improve the load capacity of a friction pile [11] and control the pore water during excavation [12]. However, the technique is in fact seldom used on a professionally recognized scale. The reluctance of the ground improvement 


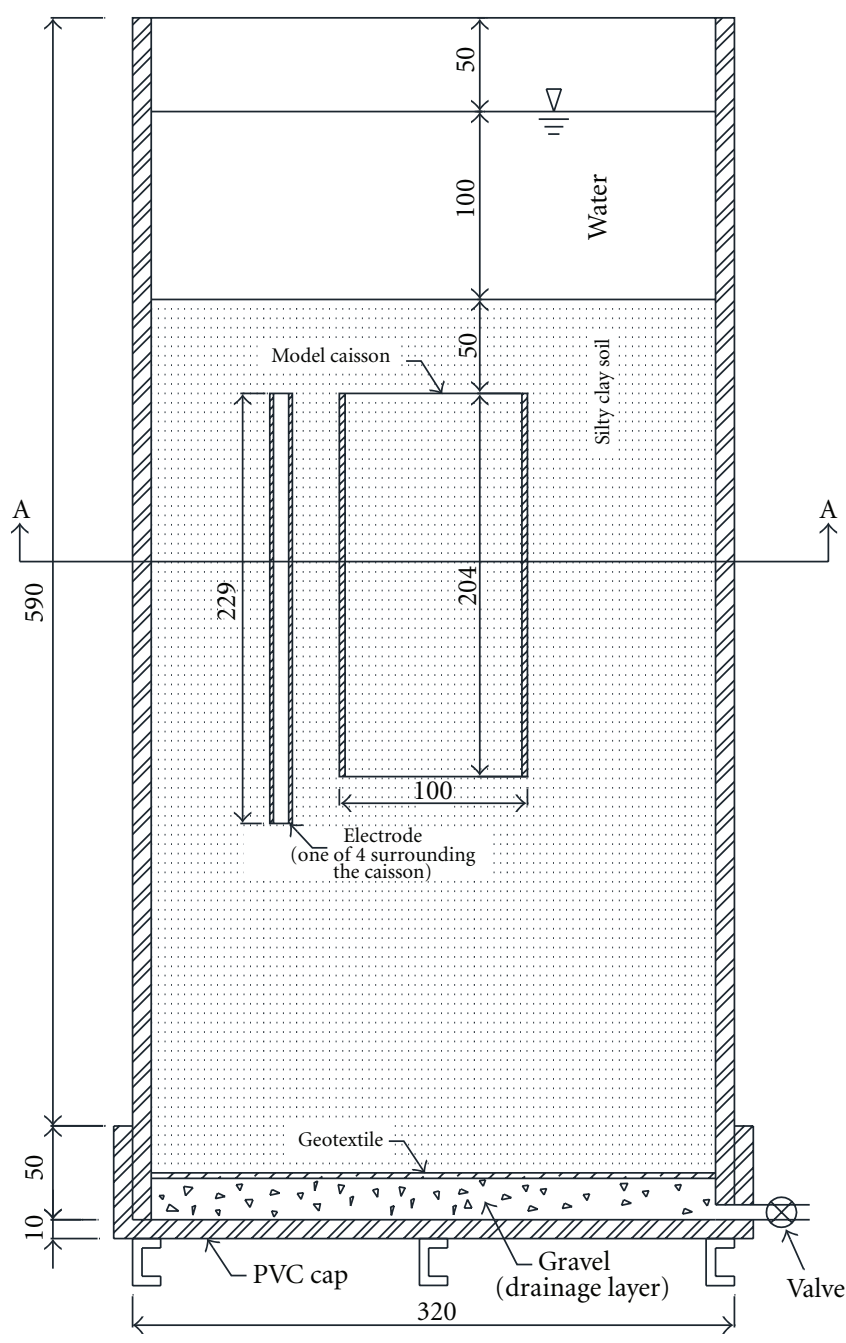

(a)

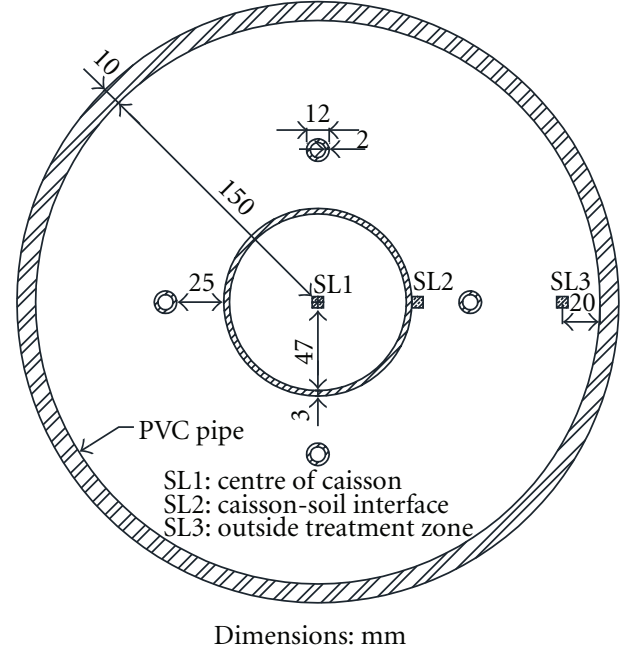

(b)

Figure 1: (a) Schematic of electrokinetic treatment cell; (b) Cross-section A-A (test 3 model caisson and configuration).

industry to embrace the technique is primarily due to the absence of design guidelines and specifications for electrokinetic treatment systems.

A critical issue that needs to be investigated and understood in order to devise design guidelines for electrokinetic treatment systems from experimental results is the effect of the foundation element size on the gained improvement. Equally important for the guideline is determining the optimum distance between the anode(s) and the cathode(s). Optimum electrode spacing focuses the electric field in the vicinity of the foundation element and controls the size of the treatment zone. Thus, the improvement in the strength properties of the soil occurs in foundation-soil interface with the lowest energy consumption. Finally, estimating the power consumption prior to an electrokinetic treatment is critical to evaluate the economic viability of the treatment. These are major issues that need to be investigated and understood in order to extrapolate, correlate, and/or model the results from bench-scale, laboratory-floor, and pilot tests for fullscale applications.
This experimental study is a preliminary step to address some of the issues important for devising guidelines for electrokinetic treatment. The study investigated the axial load capacity of model caissons with increasing dimensions embedded in soft soil under water after electrokinetic treatment. The study attempted to correlate the load capacity and energy consumption to the surface area of the model. The study proposed a formula for the distance between the electrodes.

\section{Experimental Program}

2.1. Material Properties. The soil used in this study was recovered from a construction site in Thunder Bay, ON. Grain size distribution analysis on the soil was performed in accordance with ASTM D422-63 [13] and showed that $15.5 \%$ of the soil is sand size and $84.5 \%$ is fines (silt and clay). The liquid and plastic limits of the soil, determined by ASTM D4318-10 [14], are 25 and 19, respectively. The Unified Soil 
Classification System group symbol of the soil is CL-ML and the group name is silty clay with sand. The natural water content of the soil was $36 \%$ and the specific gravity is 2.72 .

2.2. Experimental Setup and Procedure. Three identical electrokinetic treatment cells were designed and manufactured for the study. The cell, shown in Figure 1, was made from polyvinyl chloride (PVC) pipe $320 \mathrm{~mm}$ in outside diameter, $300 \mathrm{~mm}$ in inside diameter, $650 \mathrm{~mm}$ in length and with a volume capacity of 45 litres. One side of the pipe was covered with a PVC cap that served as a base for the cell. A drainage valve was installed at the base of the cell to facilitate saturation.

Four model caissons with $3 \mathrm{~mm}$ wall thickness and increasing diameters and lengths were manufactured from steel and used in the experiments. The surface area was doubled each time from the smallest to the largest model caisson. The outside diameter and length of the model caissons were $50 \mathrm{~mm}$ and $102 \mathrm{~mm}$ in test $1,75 \mathrm{~mm}$ and $136 \mathrm{~mm}$ in test 2, $100 \mathrm{~mm}$ and $204 \mathrm{~mm}$ in test 3 , and $150 \mathrm{~mm}$ and 272 in test 4 . The corresponding surface areas (SAs) were 16000 , 32000,64000 , and $128000 \mathrm{~mm}^{2}$, respectively. The tests are summarized in Table 1.

A mass of the silty clay soil was placed in a concrete mixture drum. The volume of water required to increase the water content of the soil to 50\% was measured and added to the drum. The soil and water were thoroughly mixed in the drum in order to produce a homogenous soft soil. The water content of the mixture was selected twice the liquid limit in order to produce a soil specimen with properties of reconstituted clay as described by Burland [15] and with virtually no shear strength.

Approximately $25 \mathrm{~mm}$ layer of clean gravel, $5-7 \mathrm{~mm}$ grain size diameter, was placed at the bottom of the cell as a drainage layer, which was overlain by a geotextile filter (Figure 1(a)). The soft clayey soil was then poured into the cell. The soft soil was allowed to settle and consolidate over its own weight for $48 \mathrm{hr}$. After settlement and consolidation, the soil specimen was approximately $465 \mathrm{~mm}$ high $(150 \mathrm{~mm}$ shorter than the cell) and was overlain by a layer of water. The electrical conductivity of the soil, $\sigma$, was measured using ASTM G57-6 [16] and founded to be $0.1 \mathrm{~S} / \mathrm{m}$. The model caisson was then inserted into the cell with the centre of the caisson coinciding with that of the cell. The upper of the model caisson was $50 \mathrm{~mm}$ below the soil specimen as shown in Figure 1(a). The model caisson served as the anode during the treatment. Four electrodes serving as the cathode were inserted around the model caisson at equal distance from each other. The electrode was made of perforated steel pipe, $12 \mathrm{~mm}$ outside diameter, $8 \mathrm{~mm}$ inside diameter and was $25 \mathrm{~mm}$ longer than the model caisson. The perforation holes were $3 \mathrm{~mm}$ in diameter at spacing of $13 \mathrm{~mm}$ centre-to-centre. The tops of the electrode and the model caisson were at the same level while the tip of the electrode was $25 \mathrm{~mm}$ below the base of the caisson (Figure 1(a)).

The electric field was simulated for various distances between the anode (model caisson) and the cathode (four

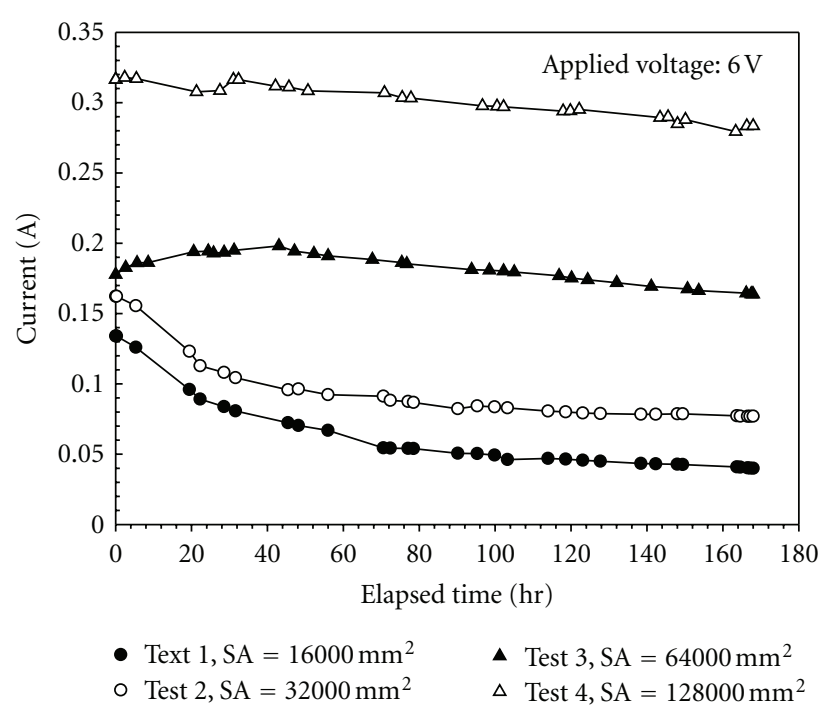

FIGURE 2: Electric current versus elapsed time of the test.

electrodes) by using QuickField [17], a field simulation software. The simulation aimed to provide the maximum electric field, and subsequently the maximum improvement in the strength properties of the soil, in the caisson-soil interface. A distance equal 0.25 times the outside diameter of the model caisson was identified as optimum for electric field between the caisson and cathode. Thus, 13, 19, 25, and $38 \mathrm{~mm}$ were the distances between electrode and model caisson in tests 1 to 4 , respectively. The plan view of the electrodes layout in test 3 is shown in Figure 1(b). After installing the model caisson and the electrodes, the water above the soil specimen was raised to $100 \mathrm{~mm}$ and kept throughout the duration of the treatment and the shear strength and axial load tests.

A direct current $(\mathrm{dc})$ voltage of $6 \mathrm{~V}$ was applied to the cell with the model caisson serving as the anode and four electrodes (A1 to A4) serving as the cathode. The electrokinetic treatment lasted for $168 \mathrm{hr}$ with current intermittence intervals of $2 \mathrm{~min}$ on and $2 \mathrm{~min}$ off executed by a programmable timer. Current intermittence, the application of a pulse voltage at predetermined on/off intervals instead of a continuous dc voltage, was selected for its superior outcome in electrokinetic treatment as well as its effectiveness in reducing corrosion of the electrodes $[7,18,19]$. The electric current was monitored and reported during the treatment. For each electrokinetic treatment test in this study, a control test with identical soil and configuration but without electric field was carried out to provide baseline data for comparison.

\section{Results and Discussion}

3.1. Electric Field and Energy Consumption. Figure 2 shows the electric current across the tank versus the elapsed time of the test. The figure shows that for the same applied voltage, the electric current increases with the increase in the surface area of the model caisson. This is due to the 


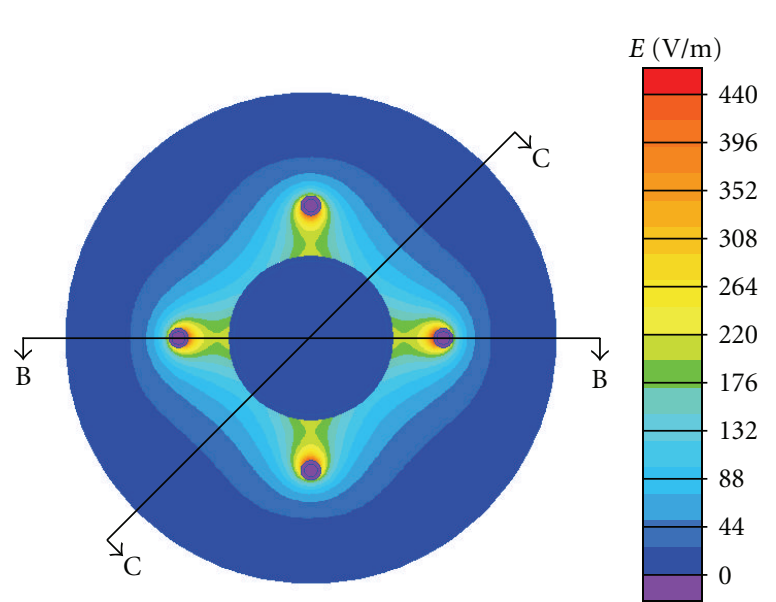

(a)

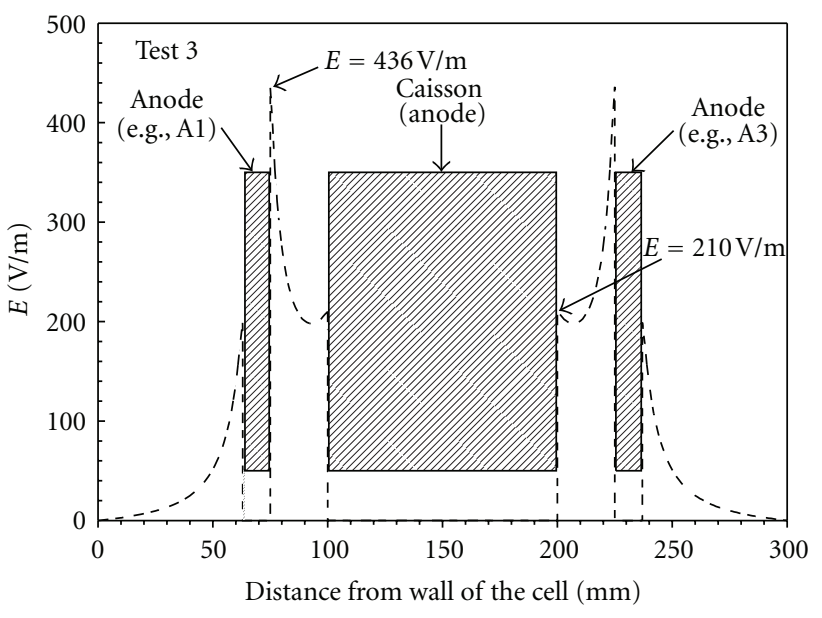

(b)

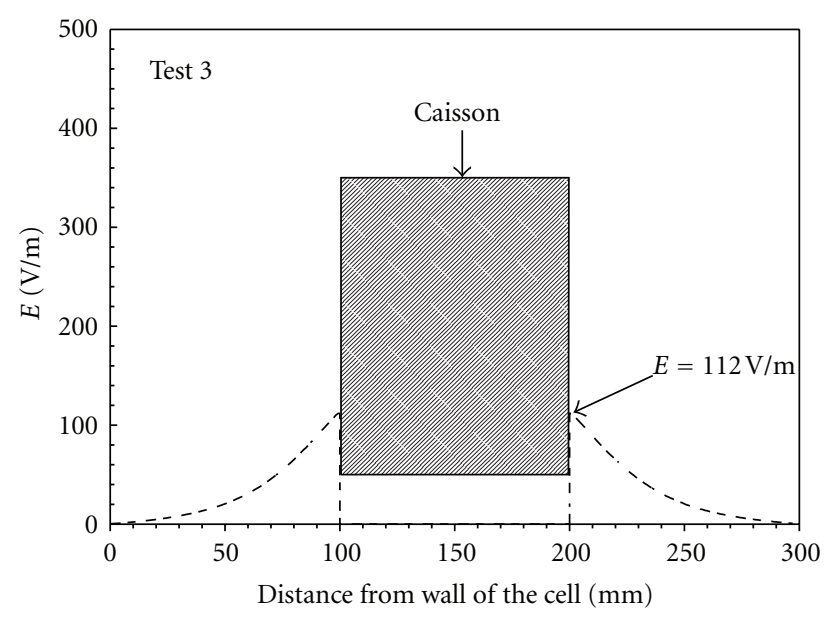

(c)

Figure 3: (a) Plan view of electric field intensity, $E(\mathrm{~V} / \mathrm{m})$, distribution in the cell; (b) $E$ along cross-section B-B of the cell; (c) $E$ along cross-section C-C of the cell.

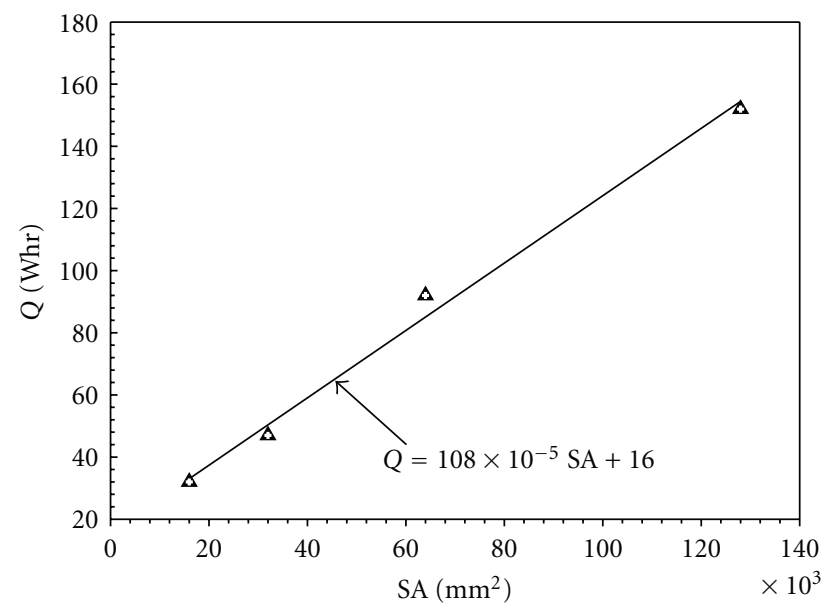

FIGURE 4: Energy consumption, Q, versus surface area, SA, of the model caisson. 
TABLE 1: Summary of tests and results.

\begin{tabular}{|c|c|c|c|c|c|c|c|c|c|c|}
\hline \multirow[b]{2}{*}{ Test } & \multicolumn{3}{|c|}{ Model caisson } & \multirow{2}{*}{$\begin{array}{l}\text { Distance between } \\
\text { electrode \& caisson } \\
\mathrm{mm}\end{array}$} & \multicolumn{2}{|c|}{ Energy consumption } & \multicolumn{2}{|c|}{$P_{f}$} & \multicolumn{2}{|c|}{ Displacement at failure } \\
\hline & $\begin{array}{l}\text { Dia. } \\
\text { mm }\end{array}$ & $\begin{array}{l}\text { Length } \\
\mathrm{mm}\end{array}$ & $\begin{array}{c}\mathrm{SA} \\
\mathrm{mm}^{2}\end{array}$ & & Control & $\begin{array}{l}\text { EK } \\
\text { Whr }\end{array}$ & $\begin{array}{c}\text { Control } \\
\mathrm{N}\end{array}$ & $\begin{array}{c}\text { EK } \\
N\end{array}$ & $\begin{array}{c}\text { Control } \\
\mathrm{mm}\end{array}$ & $\begin{array}{l}\mathrm{EK} \\
\mathrm{mm}\end{array}$ \\
\hline Test 1 & 50 & 102 & 16000 & 13 & - & 32 & 12 & 126 & 0.4 & 1.6 \\
\hline Test 2 & 75 & 136 & 32000 & 19 & - & 47 & 45 & 205 & 1.0 & 1.2 \\
\hline Test 3 & 100 & 204 & 64000 & 25 & - & 92 & 84 & 327 & 0.4 & 1.1 \\
\hline Test 4 & 150 & 272 & 128000 & 38 & - & 152 & 170 & 521 & 0.6 & 0.8 \\
\hline
\end{tabular}

EK: electrokinetic.

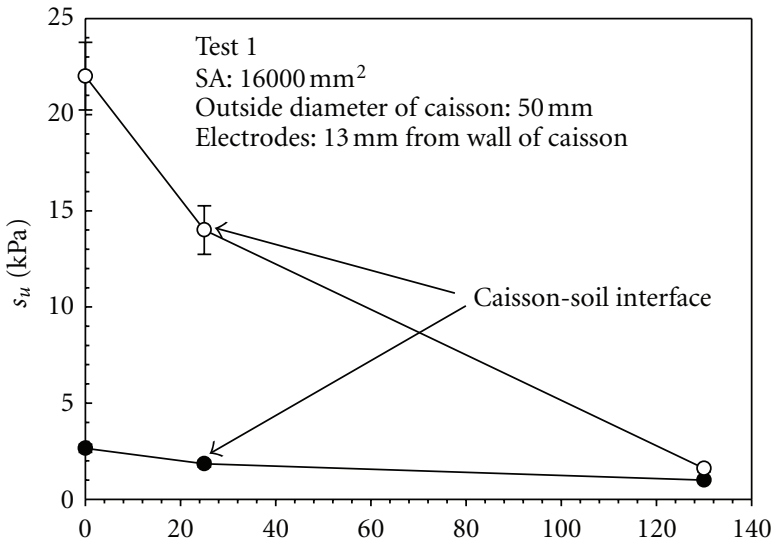

(a)

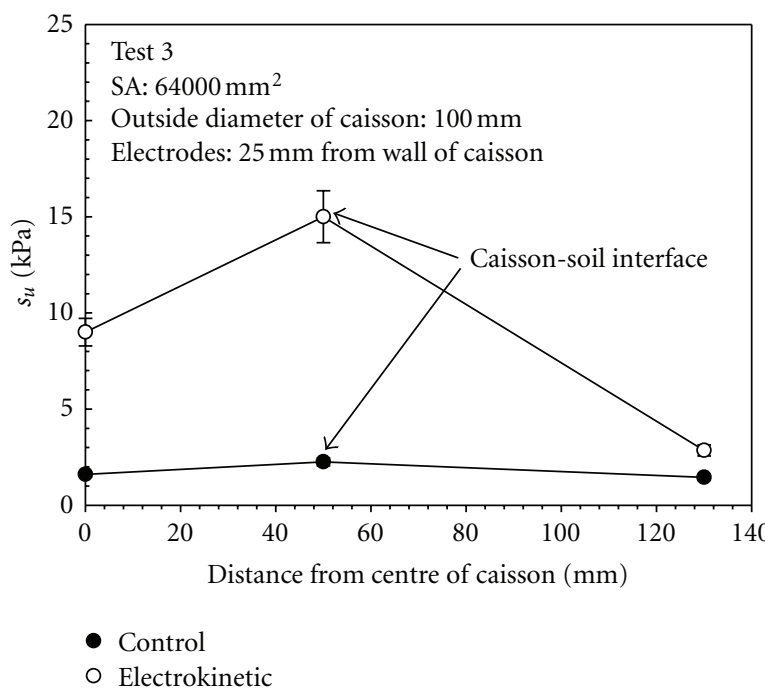

(c)

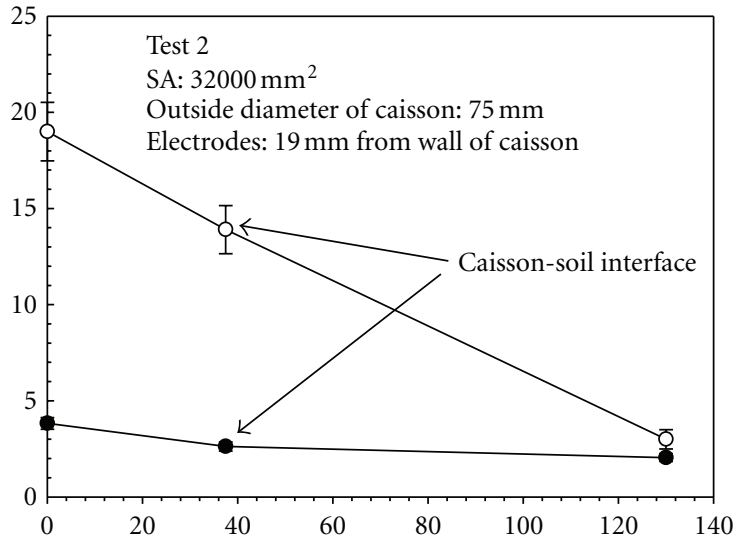

(b)

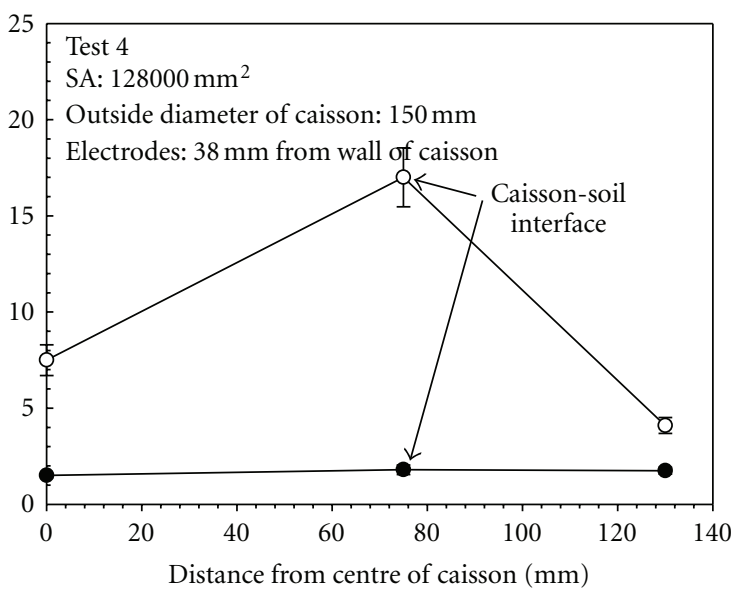

- Control

○ Electrokinetic

FIgURE 5: Undrained shear strength, $s_{u}$, versus distance from the centre of model caisson.

increase in the soil area subject to the electric current as the caisson increases. The electric current values shown in Figure 2 represent the integration of the current density over the soil area subjected to the current. As the surface area of the caisson increases, the area in the soil subjected to the current increases and so does the current.

Figure 2 shows electric current in tests 1 and 2 decreased throughout the test with the sharpest decrease occurring during the first $20 \mathrm{hr}$. In test 3, the current increased with time during the first $40 \mathrm{hr}$ of the test. After, the current decreased slightly with time up to the end of the test. In test 4, the current slightly deceased during the first $20 \mathrm{hr}$ of the test and then increased. The current then decreased with small rate until the end of the test. The change in electric current with time as shown in Figure 2 resulted from the change in electrical conductivity of the soil during the test. The change in the conductivity of soil during an electrokinetic process is a result of two opposing mechanisms. In general, as the pore 
fluid drained out of the soil mass (pore fluid dominates the bulk conductivity of the soil) by electroosmosis, the bulk electrical conductivity of the soil decreases. However, for water still remaining inside the soil pores, the electrical conductivity increases with the treatment time as a result of electrolytic reactions associated with the electrokinetic process $[20,21]$. Therefore, the increase in the electrical conductivity of the pore fluid by the electrolytic reactions can sometimes become more dominant than the decrease in conductivity of the soil resulting from the draining of water. Thus the bulk conductivity of the soil, and thereby the electric current, may start to increase sometime after the start of the electrokinetic treatment as observed in tests 3 and 4 . However, Figure 2 suggests that for all tests, the change in current and thereby the change in electrical conductivity was very small during most of the testing time.

Figure 3(a) shows distribution of the electric field intensity, $E$, during test 3 simulated using QuickField. The $E$ distribution shown in Figure 3(a) was typical in all the tests. Figures 3(b) and 3(c) show plan views of $E$ across the centre of the cell and two electrodes (section B-B) and across the centre of the cell and midway between electrodes (section $\mathrm{C}-\mathrm{C}$ ) for test 3 . As shown in the figures, the highest $E$, and subsequently the highest current density (current density = $E \sigma)$, occurred in the vicinity of the caisson. In test $3, E$ varied between 112 and $210 \mathrm{~V} / \mathrm{m}$ (i.e., current density between 11.2 and $21 \mathrm{~A} / \mathrm{m}^{2}$ ) in the model caisson-soil interface compared to $E$ and current density of zero in the soil near the wall of the cell.

The energy consumption, $Q$, during electrokinetic treatment was calculated for each test and is shown in Figure 4 versus the surface area (SA) of the model caisson. As shown in the figures, $Q$ increased linearly with $S A$ as

$$
Q(\mathrm{Whr})=108 \times 10^{-5} \mathrm{SA}\left(\mathrm{mm}^{2}\right)+16 .
$$

Thus, for soil with electrical conductivity of $0.1 \mathrm{~S} / \mathrm{m}$, applied voltage of $6 \mathrm{~V}$, and electrodes layout similar to the configuration in this study, the energy consumptions per week of treatment can be estimated by (1).

3.2. Undrained Shear Strength. After the completion of the electrokinetic treatment, the undrained shear strength, $s_{u}$, was measured in three locations shown in Figure 1(b) (SL1, SL2, and SL3) using a shear vane. At each location $s_{u}$ was measured at the top, mid, and bottom levels of the model caisson. An average value for $s_{u}$ was determined from the three measurements for each location and presented in Figure 5 . After the treatment, the average $s_{u}$ varied between $14 \pm 1.3 \mathrm{kPa}$ and $17 \pm 1.5 \mathrm{kPa}$ in the model caisson-soil interface (SL2) and between $1.6 \pm 0.2 \mathrm{kPa}$ and $4.1 \pm 0.5 \mathrm{kPa}$ at $130 \mathrm{~mm}$ from the centre of the caisson (SL2). The corresponding $s_{u}$ in the control tests ranged from $1 \pm 0.1 \mathrm{kPa}$ to $2.6 \pm 0.2 \mathrm{kPa}$. The relationship between the magnitude of the electric field (stronger in the vicinity of the model caisson and weaker away from the caisson) and gained strength in the soil are illustrated for test 3 by Figures 3(b) and 5. At SL2, $201 \mathrm{~V} / \mathrm{m} \geq E \geq 112 \mathrm{~V} / \mathrm{m}$ and $s_{u}=15 \pm 1.3 \mathrm{kPa}$ whereas

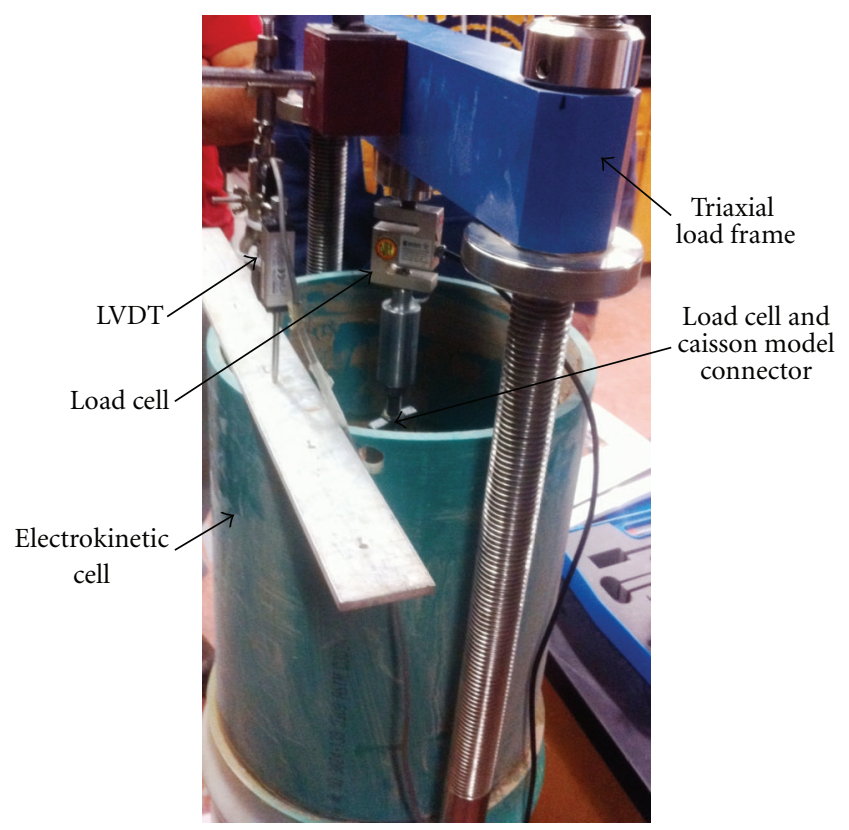

FIGURE 6: Electrokinetic cell during axial load testing for the model caisson.

at SL3, $E \leq 7 \mathrm{~V} / \mathrm{m}$ and $s_{u} \leq 2.8 \pm 0.3 \mathrm{kPa}$. Thus focusing the electric field near the caisson significantly increased $s_{u}$ in the caisson-soil interface as, a primary objective of the optimizing the distance between the electrodes while $s_{u}$ away from the caisson remained approximately similar to that of the control.

As shown in Figure 5, the treatment also increased the strength of the soil inside the model caisson (SL1) with the highest shear strength reported in tests 1 and 2 . The higher strength in tests 1 and 2 was likely due to the smaller size of the model caissons in the two tests. As the size of the model caisson deceased, more water was drained by electroomosis out of the enclosed soil since the caisson was serving as an anode. Increasing shear strength for soil inside a foundation element can generate a soil plug. For caisson foundations, a soil plug adds a toe bearing resistance component and thereby increases the axial load capacity.

3.3. Axial Load Capacity. After measuring $s_{u}$, the model caisson was axially loaded to failure by a triaxial load frame as shown in Figure 6. Figure 7 shows the axial load capacity, $P$, versus the vertical displacement of the model caisson after the electrokinetic treatment and for the control tests. The axial load capacity at failure, $P_{f}$, is marked on the figure. $P_{f}$ was determined by the failure criterion proposed by Tani and Craig [22]. In this failure criterion, the failure was at the point of intersection of the load-displacement curve and the bisector line of the angle made by two tangents on both sides of the sharp bend of the load-displacement curve. As shown in Figure 7, $P_{f}$ after electrokinetic treatment was $126 \mathrm{~N}$ in test $1\left(\mathrm{SA}=16000 \mathrm{~mm}^{2}\right), 205 \mathrm{~N}$ in test $2(\mathrm{SA}=$ $\left.32000 \mathrm{~mm}^{2}\right), 327 \mathrm{~N}$ in test $3\left(\mathrm{SA}=64000 \mathrm{~mm}^{2}\right)$, and $521 \mathrm{~N}$ 


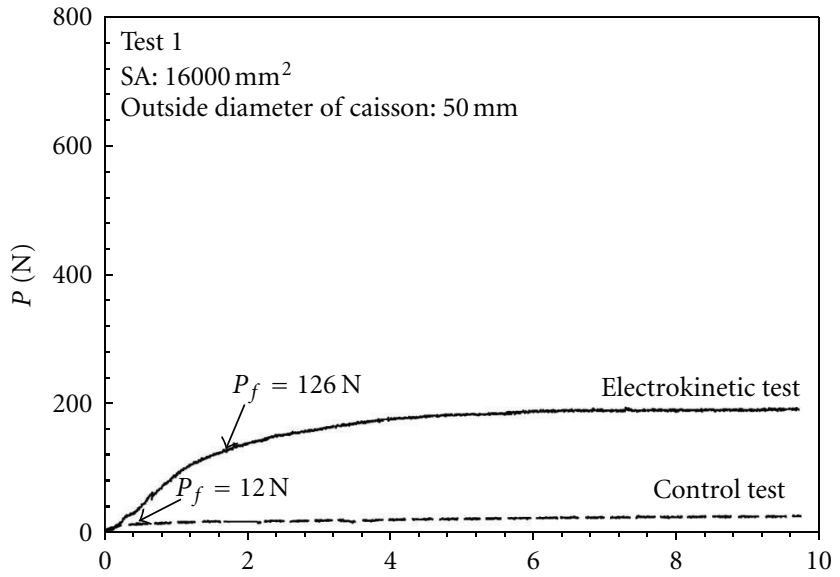

(a)

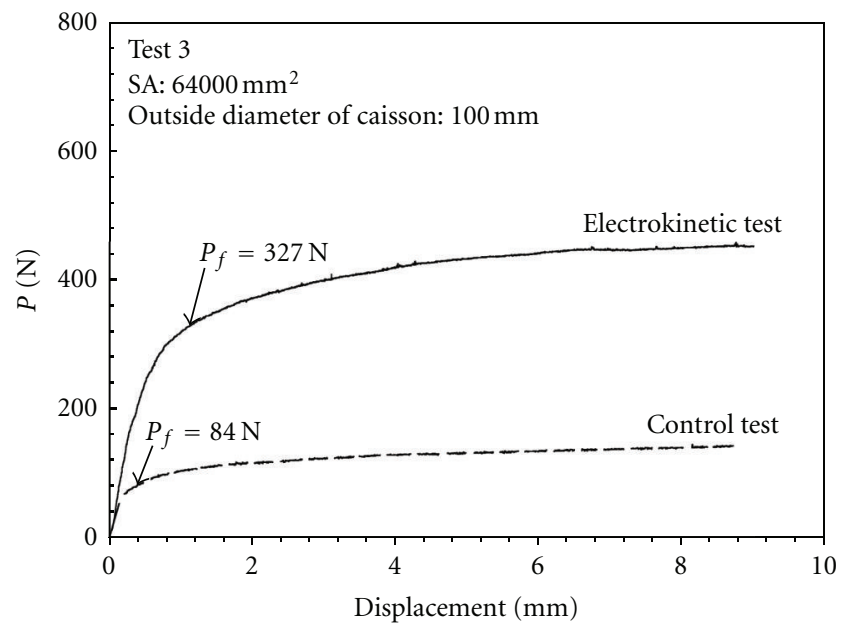

(c)

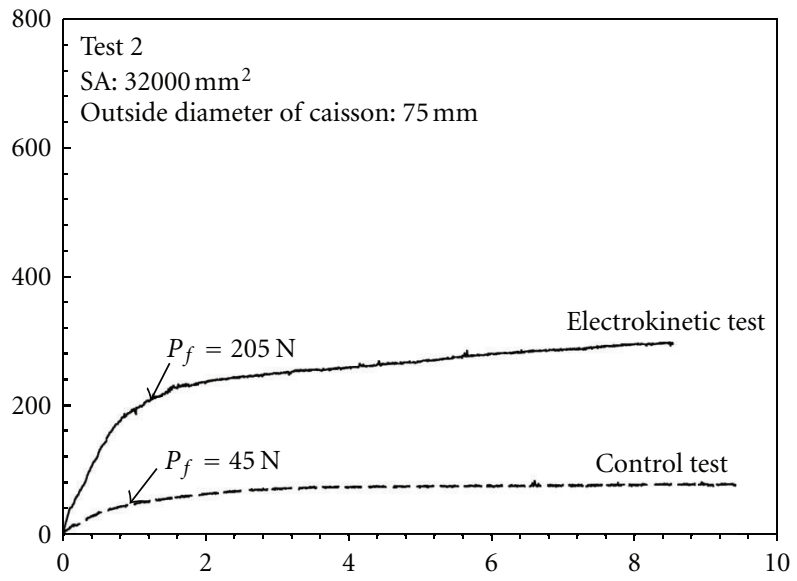

(b)

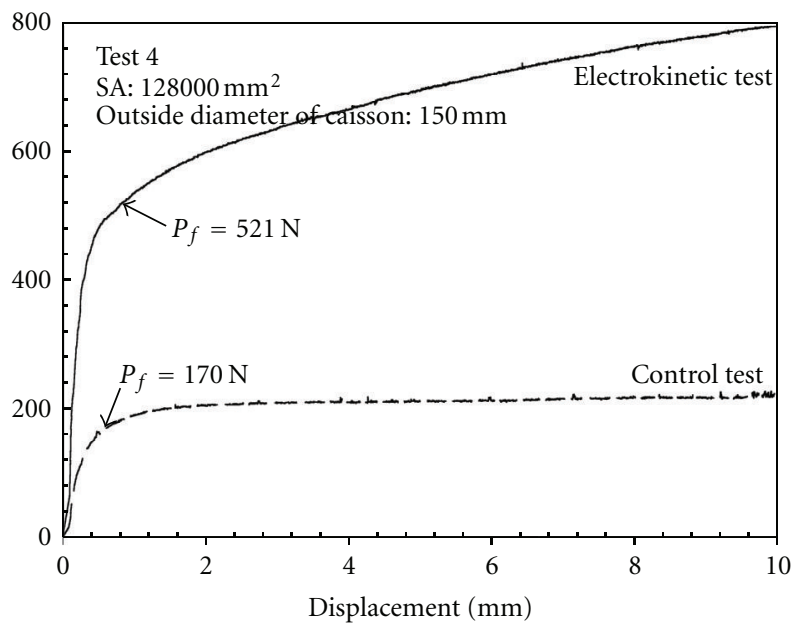

(d)

Figure 7: Axial load capacity, $P$, versus vertical displacement of the model caisson.

in test $4\left(\mathrm{SA}=128000 \mathrm{~mm}^{2}\right)$. The corresponding $P_{f}$ values in the control tests were $12,45,84$, and $170 \mathrm{~N}$, respectively. This represents an increase between 206 and $950 \%$ after electrokinetic treatment as compared to the control.

Figure 8 shows $P_{f}(\mathrm{~N})$ versus the surface area, $\mathrm{SA}\left(\mathrm{mm}^{2}\right)$ of the model caisson for the four tests. As shown in the figure, $P_{f}$ varied linearly with SA for the range covered in this study and the relationship is given by:

Control tests:

$$
P_{f}(\mathrm{~N})=1373 \times 10^{-6} \mathrm{SA}\left(\mathrm{mm}^{2}\right)-4 .
$$

Electrokinetic treatment tests:

$$
P_{f}(\mathrm{~N})=3458 \times 10^{-6} \mathrm{SA}\left(\mathrm{mm}^{2}\right)+87 .
$$

A linear relationship between $P_{f}$ and SA is expected in the control tests as the commonly used formulas for the axial load capacity are linear function between the soil properties and the dimensions of the foundation elements. A linear relationship between $P_{f}$ and SA after an electrokinetic

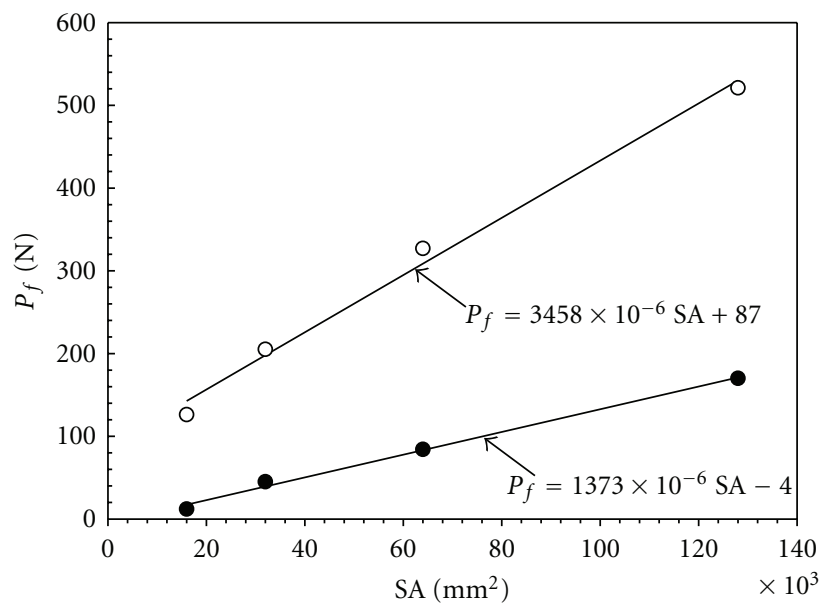

- Control

○ Electrokinetic

Figure 8: Axial load capacity at failure, $P_{f}$, versus surface area, SA, of the model caisson. 
treatment means that the improvement in the strength properties of the soil after the treatment is independent caisson foundation dimensions. This is very important as it allows a preliminary estimation of the axial capacity for full-scale foundation element from laboratory testing of much smaller models. For example, $P_{f}$ for a caisson foundation with a diameter of $1 \mathrm{~m}$ and a length of $8 \mathrm{~m}$ (SA $=25 \mathrm{~m}^{2}$ ) inserted in soil with geotechnical properties similar to the silty clay used in this study and under water can be estimated from (2) as $34 \mathrm{kN}$. However, after an electrokinetic treatment with electric field configuration similar to the configuration in this study, $P_{f}$ is estimated by $(3)$ as $87 \mathrm{kN}$ and the corresponding energy consumption from (1) is $27 \mathrm{kWhr}$.

\section{Conclusions}

This experimental study aimed to investigate some parameters that are critical for devising design guidelines for electrokinetic treatment. Four model caisson with surface areas between 16000 and $128000 \mathrm{~mm}^{2}$ were embedded in soft clayey soil under water and treated with a dc voltage of $6 \mathrm{~V}$ for $168 \mathrm{hr}$. From the study we can conclude the following.

(i) The axial load capacity of the caissons after the electrokinetic treatment varied between 126 and $521 \mathrm{~N}$ compared to 12 to $170 \mathrm{~N}$ in the control tests.

(ii) A distance between the anode (model caisson) and the cathode equal 0.25 times the outside diameter of the caisson was identified as optimum.

(iii) A relationship between the surface area and the axial capacity of the caisson was presented. The equation can be used to preliminary estimate the load capacity of a full-scale foundation element after an electrokinetic treatment.

(iv) A correlation between the surface area of the caisson and the energy consumption was presented. The correlation can approximately predict the energy consumption for full-scale applications prior to treatment.

\section{Acknowledgments}

There is no financial gain for any of the authors of the paper for using Quickfield in this research. The authors wish to thank Mr. Conrad Hagstrom, Civil Engineering at Lakehead University and LH North General Contractor Limited for their valuable help during this research. The research is funded by Natural Science and Engineering Research Council of Canada (NSERC).

\section{References}

[1] M. I. Esrig, "Pore pressure, consolidation and electrokinetics," Journal of the Soil Mechanics and Foundations Division, vol. 94, no. 4, pp. 899-921, 1968.

[2] S. Micic, J. Q. Shang, and K. Y. Lo, "Electrocementation of a marine clay induced by electrokinetics," International Journal of Offshore and Polar Engineering, vol. 13, no. 4, pp. 308-315, 2003.

[3] J. Q. Shang, "Electrokinetic dewatering of clay slurries as engineered soil covers," Canadian Geotechnical Journal, vol. 34, no. 1, pp. 78-86, 1997.

[4] L. Casagrande, "Electroosmosis in soil," Géotechnique, vol. 1, no. 3, pp. 159-177, 1949.

[5] L. Casagrande, "Electro-osmosis stabilization of soils," Journal of the Boston Society of Civil Engineers, vol. 39, no. 1, pp. 51-83, 1983.

[6] J. Q. Shang and K. S. Ho, "Electro-osmotic consolidation behavior of two Ontario clays," Geotechnical Engineering, vol. 29, no. 2, pp. 181-194, 1998.

[7] S. Micic, J. Q. Shang, K. Y. Lo, Y. N. Lee, and S. W. Lee, "Electrokinetic strengthening of a marine sediment using intermittent current," Canadian Geotechnical Journal, vol. 38, no. 2, pp. 287-302, 2001.

[8] L. Bjerrum, J. Moun, and O. Eide, "Application of electroosmosis to a foundation problem in a Norwegian quick clay," Géotechnique, vol. 17, no. 3, pp. 214-235, 1967.

[9] K. Y. Lo, K. S. Ho, and I. I. Inculet, "Field test of electroosmotic strengthening of soft sensitive clay," Canadian Geotechnical Journal, vol. 28, no. 1, pp. 74-83, 1991.

[10] F. Burnotte, G. Lefebvre, and G. Grondin, "A case record of electroosmotic consolidation of soft clay with improved soilelectrode contact," Canadian Geotechnical Journal, vol. 41, no. 6, pp. 1038-1053, 2004.

[11] V. Milligan, "First application of electro-osmosis to improve friction pile capacity-three decades later," Proceedings of the ICE: Geotechnical Engineering, vol. 113, no. 2, pp. 112-116, 1995.

[12] W. Perry, "Electro-osmosis dewaters large foundation excavation," Construction Methods and Equipment, vol. 45, no. 9, pp. 116-119, 1963.

[13] ASTM, "Standard test method for particle-size Analysis of soils," Annual Book of ASTM Standards-Construction D422-63, ASTM, West Conshohocken, Pa, USA, 2007.

[14] ASTM, "Standard test methods for liquid limit, plastic limit, and plasticity index of soils," Annual Book of ASTM Standards-Construction D4318-10, ASTM, West Conshohocken, Pa, USA, 2007.

[15] J. B. Burland, "On the compressibility and shear strength of natural clays," Géotechnique, vol. 40, no. 3, pp. 329-378, 1990.

[16] ASTM, "Standard method for field measurement of soil resistivity using the wenner-four electrode method," Annual Book of ASTM Standards-Construction G57-06, ASTM, West Conshohocken, Pa, USA, 2006.

[17] Tera Analysis Ltd, “QuickField,” Knasterhovvej 21, DK-5700, Svendborg, Denmark, 2011.

[18] R. H. Sprute and D. J. Kelsh, Limited Field Tests in Electrokinetic Densification of Mill Tailings, vol. 8034, U.S. Department of Interior, United States Bureau of Mines Report of Investigations, Washington, DC, USA, 1975.

[19] E. Mohamedelhassan and J. Q. Shang, "Effects of electrode materials and current intermittence in electro-osmosis," Ground Improvement, vol. 5, no. 1, pp. 3-11, 2001.

[20] B. Narasimhan and R. Sri Ranjan, "Electrokinetic barrier to prevent subsurface contaminant migration: theoretical model development and validation," Journal of Contaminant Hydrology, vol. 42, no. 1, pp. 1-17, 2000.

[21] E. Mohamedelhassan and J. Q. Shang, "Electrokineticsgenerated pore fluid and ionic transport in an offshore 
calcareous soil," Canadian Geotechnical Journal, vol. 40, no. 6, pp. 1185-1199, 2003.

[22] K. Tani and W. H. Craig, "Bearing capacity of circular foundations on soft clay of strength increasing with depth," Soils and Foundations, vol. 35, no. 4, pp. 21-35, 1995. 

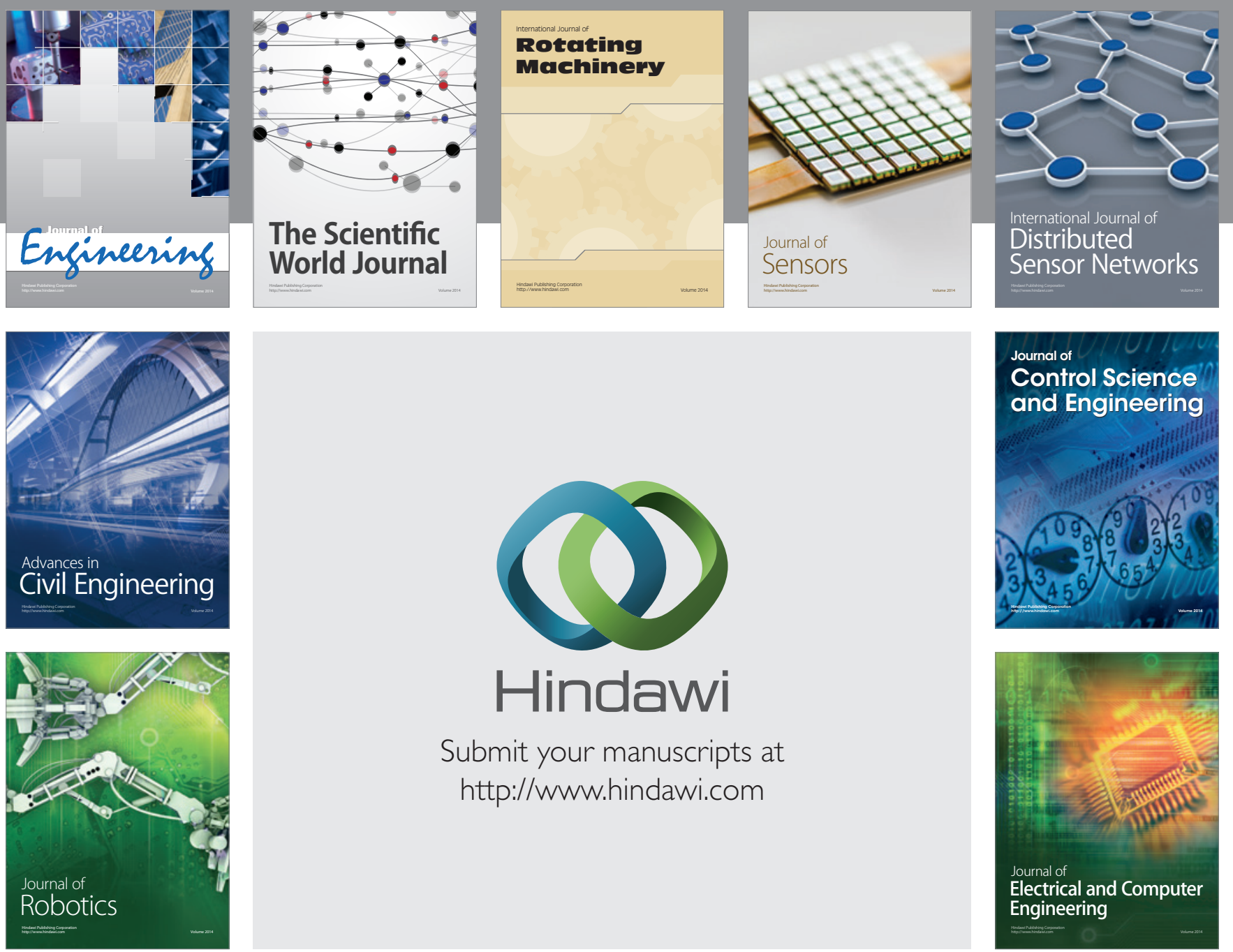

Submit your manuscripts at

http://www.hindawi.com
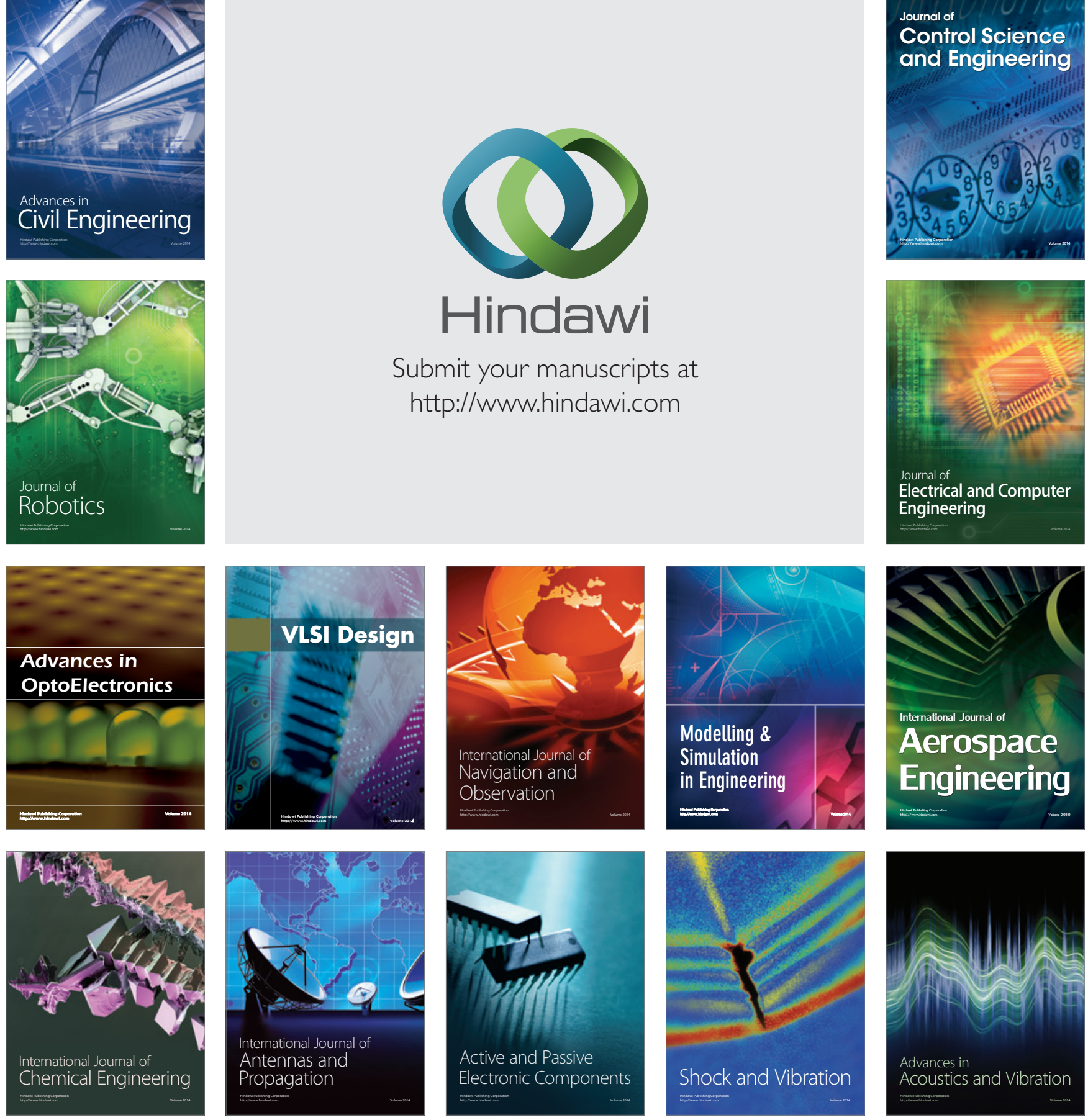